УДК 23:658.588.2

DOI 10.35423/2078-8142.2021.2.1.3

В. П. Литовченко, кандидат філософських наук, дочент кафедри соиіально-гуманітарних дисциплін ВП НУБіП Украйни «Ніжинський агротехнічний інститут», м. Ніжин, Украӥна e-mail:viktorpl08@gmail.com ORCID: https://orcid.org/0000-0003-0532-0188

\title{
ЕКЗИСТЕНЦІЙНІ ВИМІРИ ЧОРНОБИЛЬСЬКОЇ КАТАСТРОФИ У СВІДЧЕННЯХ ПЕРШИХ ЛІКВІДАТОРІВ
}

Актуальність обраної теми статті зумовлена відсутністю належного наукового дискурсу в контексті особистісних переживань рядових ліквідаторів аварії на Чорнобильській атомній електростанції. Полеміка науковиів Радянського Союзу зосередила свої зусилля передусім на причинах та наслідках техногенної катастрофи, тоді як питання конституювання иінності людського життя, особистих сумнівів та переживань, світоглядних позиџій ліквідаторів в умовах невідворотної та невидимої небезпеки оминалися в наукових публікаціях, або висвітлювалися поверхово. На основі відкритих джерел (фрагментарних спогадів ліквідаторів аваріі) представлені свідчення людського героїзму і легковажності; відвертого нехтування елементарними правилами техніки безпеки і прагнення убезпечитися простими народними методами; крайніх виявів людського егоїзму та альтруіззму. Проблема надзвичайно актуалізується тому, що за руйнівними наслідками небаченої раніше катастрофи украйнське суспільство, вже вкотре, не спромоглося зрозуміти того, щзо життя Людини є найбільшою цінністю на Землі. Здійснено аналіз спогадів-переконань ліквідаторів з позииії виявлення екзистенційних маркерів співіснування людського соиіуму в умовах радіачійного забруднення. У статті екзистенція героя-рятівника визначається через концепти «тривоги», «страху», «побуту», «гумору» та ін. Зроблено висновок, щуо чорно-

(C) Литовченко В. П., 2021 
бильська катастрофа відкрила невідомі раніме прояви амбівалентності в житті особистості, стала тестом на нашу громадську зрілість.

Ключові слова: чорнобильська трагедія, радіація, опромінення, ліквідатори, страх, переживання.

Глобальні катастрофи постійно перебувають у сфері досліджень науковців багатьох країн. Однією з найбільших у світі є аварія на Чорнобильській атомній електростанції, яка сталася 26 квітня 1986 р. Непоправні екологічні наслідки катастрофи для України та світу визнала світова спільнота, яка 8 грудня 2016 р. на Генеральній Асамблеї Організації Об'єднаних Націй ухвалила резолюцію, якою проголосила 26 квітня Міжнародним днем пам'яті про чорнобильську катастрофу.

Сучасна література містить значну джерельну базу стосовно аварії на ЧАЕС. Для загального доступу відкриті численні наукові, публіцистичні, мемуарні та художні публікації, які розкривають історію найбільшої в Україні техногенної катастрофи. Водночас, суто філософське осмислення Чорнобильської трагедії стоїть чи не найнижчому шаблі. Це, певним чином, можна пояснити нагальністю вирішення передусім екологічних, економічних, демографічних та інших наслідків катастрофи. Екзистенційні переживання рядових ліквідаторів аварії на ЧАЕС, пересічних громадян не були предметом серйозних аналітичних досліджень позаяк визначалися як не ідеологічно витримані, не важливі, не актуальні. Такий стан речей дає Ю. О. Каганову можливість констатувати, що «радянський академічний дискурс був складовою механізму конструювання комуністичного типу людини і нездатним на його об'єктивне висвітлення у філософській, історичній, соціологічній та інших площинах. Образ «будівника комунізму», трансльований у подібних наукових працях, відображав не реальний тип людини, а передусім ідеального громадянина з точки зору політичних еліт СРСР: керованого, залежного від держави, уніфікованого культурно та політично» [1, с. 25]. На жаль, названа вище художня традиція значною мірою успішно перекочувала і в науковий дискурс незалежної України. 
Тож, метою даної статті є встановлення, аналіз і узагальнення внутрішніх переживань тих ліквідаторів аварії на ЧАЕС, які були залучені військовими комісаріатами в перші дні катастрофи й зустріли смертельну небезпеку радіації в добу ії найбільшого випромінення. Актуальність подібних досліджень визначається і тим, що пізніші «домашні» оповідки даних ліквідаторів стали одним 3 важливих чинників національного збурення, що, своєю чергою, сприяв пробудженню українського народу й усвідомлення себе нацією.

Сам факт приховування вибуху на Чорнобильській атомній електростанції заклав міцні підвалини страхові, відчаю, непорозумінню всьому суспільному організмові. Теза про «мирний атом» так переконливо в'їлася у свідомість кожного громадянина СРСР, що навіть реальна глобальна катастрофа не змусила вище керівництво країни вчасно поінформувати громадськість про смертельну небезпеку.

Це нині наш інформаційний простір перенасичений тривожними повідомленнями та емоційно-насиченим контентом на кшталт «смертельна хвороба», «ризик зараження» тощо. У середині 80-х років минулого століття рівень усвідомлення реальної ситуації, страхів, переживань та сподівань значною мірою формувався не так від офіційних засобів масової інформації, як від «народної комунікації» - чуток. Останні послужили засобом «народної верифікації» офіційної інформації через дихотомію правда/брехня.

Джерельну базу нашого дослідження становлять свідчення безпосередніх ліквідаторів аварії на ЧАЕС. Так, людиновимірний погляд на події в Чорнобилі продемонстрував М. А. Пронін [2]. У монографічному дослідженні автор аналізує реалії перебування у зоні відчуження, передає умови праці, побут, дозвілля, гумор ліквідаторів. Трагічне, комічне, буденне, абсурдне щоденно визначало екзистенцію рядових ліквідаторів. На жаль, подібні праціє винятком iз загального масиву «чорнобильської літератури». Цьому є логічне пояснення. Тодішня ідеологія вимагала чергового подвигу трудового народу та переможних новин, не зважаючи на ціну подібних звершень.

Окрему категорію становлять численні свідчення ліквідаторів, які з'являються у засобах масової інформації з нагоди чергової річниці чорнобильської трагедії. Представлені свідчення значною мі- 
рою зумовлені та розмиті впливом часу, водночас сконцентровані у спогадах, в яскравій образно-логічній формі з усіма «незабутніми» подіями, ситуаціями, обставинами. Далі ми спробуємо виокремити стрижневі спогади, які визначали перебування ліквідаторів у зоні відчуження, «контакт» 3 радіаційним випромінюванням, вибудову міфотворчих сюжетів. Саме в них ми віднаходимо екзистенційні саме «чорнобильські» маркери: страх, відчай, абсурдність буття, приреченість, прагнення до внутрішньої свободи тощо. За відправну точку нашої рефлексії визначимо страх, адже вважаємо, що він є одним 3 найважливіших чинників, що визначає спосіб почувань і дій в екстремальному та невідомому середовищі.

Чи не найлегший спосіб взаємодії зі страхом - це його уникання, ігнорування (тим більше, що радіаційне опромінення невидиме). Це визначається природною сутністю людини, бажанням захиститися від певної небезпеки, що загрожує нашому існуванню. Як i на соціальному рівні людина уникає небажаних, пов'язаних зі страхом, небезпекою контактів, або подій, на психічному рівні ховається у схронах підсвідомого. Заглиблення, втечу в несвідоме людина розглядає як порятунок, який у жодному разі не варто ототожнювати з боягузтвом, проявом слабкості. Страх може бути зумовлений обачливістю, природним захисним механізмом будь-якої живої істоти.

Водночас, варто констатувати, що негативні переживання мобілізованих на військові збори осіб у названий час аж ніяк не можна вважати панічними. По-перше, подібні збори час від часу справді проводилися на місцевому рівні в теплу пору року. По-друге, вони ніколи не були тривалими в часі. По-третє, перебування зі своїми знайомими, колегами створює більш-менш комфортні умови перебування в будь-якому місці. Тому основна маса мобілізованих тимчасово зводила себе до ролі так званих в народі «партизан» - осіб, які перебувають у запасі для комплектування Збройних Сил та інших військових формувань на особливий період, а також для виконання робіт із забезпечення оборони держави. Тобто в уяві рядових ліквідаторів глобальна катастрофа уявлялася не більше, ніж чергова заморочка вищого керівництва, яку потрібно задовольнити й швидше повернутися додому. 
Першу більш-менш чітку інформацію про аварію та пов'язані 3 нею відчай та перестороги мобілізовані почули в обласних пунктах збору від тамтешніх офіцерів. Щоправда, такі повідомлення мали не так практичний зміст, як фольклорно-філософські настанови: про корисність алкоголю у боротьбі з радіацію, про дієвий захист свинцевими пластинами від будь-якої радіації, про корисність дозиметрів тощо. Пізніше ці настанови та власний життєвій досвід трансформувалися у різного роду історії про буття в умовах небезпечного опромінення. Такі історії, які нині вже стали бувальщиною, опосередковано засвідчують повну неготовність СРСР до ліквідації наслідків радіаційного забруднення територій. Ліквідація останніх у дусі тоталітарної традиції відбувалася нещадною експлуатацією людського ресурсу.

Безпосередньо спілкуючись з ліквідаторами аварії на ЧАЕС, ознайомлюючись 3 їхніми спогадами в літературі, електронних ресурсах мимоволі натрапляємо на близькі, але водночас слабодотичні чи суперечливі свідчення. Такі розбіжності певною мірою можна пояснити функціональними обов'язками ліквідаторів. Пожежник, лікар, шофер, повар та представники інших спеціальностей створювали власну антропологічну картину ліквідатора. Не забуваймо також те, що картина ліквідації наслідків Чорнобильської катастрофи має й суто екзистенційну періодизацію. У контексті власного світогляду кожен ліквідатор має свою особисту «катастрофу». Одна справа перебувати в зоні ураження у перші дні після аварії, перший місяць, рік, а інша - виконувати свої функції у вже облаштованому й повнофункціональному середовищі. Йдеться не так про значущість та внесок, як про антропологізм катастрофи - для кожного він свій, зі своїми передумовами, перебігом та наслідком.

Які мають бути відчуття у перших ліквідаторів, якщо для виконання найелементарніших завдань не вистачає обладнання та засобів захисту? «Уся техніка і спецзасоби «батальйону приречених» знаходилась на складах «НЗ» та складах поточного забезпечення. Лопата та марлевий респіратор («пелюстка») - ось все, що було на «озброєнні» [3]. Чи не тому спогади ліквідатора, який вижив у подібних умовах, насичена болючою морально-психологічною термінологією. Пройшовши «пекло» зі своїм «батальйоном приречених», учасники тих подій через десяток років, збираючи довідки для вста- 
новлення інвалідності, наштовхуються на антигуманний бюрократичний вирок: «Той, хто був Там, уже помер».

Чи не всі ліквідатори одноголосно стверджують, що сам рівень радіаційного забруднення території, опромінення ліквідаторів визначався ледь не «на око» й був предметом різного роду маніпуляцій. Зокрема, самі дозиметри були підлаштовані не реагувати належним чином на опромінення й значно занижували покази. Абсурдність ситуації посилюється досить частими спогадами про відсутність будь-якого захисту від радіаційного опромінення. «Жодних захисних засобів, крім армійських респіраторів, у нас не було. Байки про свинцеві жилети, суперчоботи, а також про горілку й вино, яке нібито видавали кожному, хто працював тоді на станції, я почув, повернувшись до Києва... Мій Чорнобиль - це станційний сморід, ящик «Миргородської» на роту, яка гризе землю під 3-м енергоблоком (за нами мали йти шахтарі)... Накопичувачі, які мали рахувати наші рентгени, виходили з ладу... Дозу опромінювання визначали так: зміна виходила на ділянку і дозиметрист знімав показники. Якщо дозиметр вказував, скажімо, 6 рентген на годину, то за пів години роботи записували три рентгени» [4].

Подібні «розрахунки» опромінення фіксуються і в спогадах ліквідаторів інших спеціальностей (наприклад, серед водіїв, які займалися дезактивацією території, де мав будуватися саркофаг та в навколишній 30 км зоні). Звідси дисгармонія у функціонуванні суспільної системи породила чергову ситуацію абсурду - дискомфорт і буття-страждання пересічних людей. Коли ліквідатор почав оформляти документи на оформлення інвалідності у зв'язку з перебуванням у зоні ураження, то архівний документ зазначив: «Доза опромінення не вказана. Журнал доз опромінення особового складу в/ч 18576 знищений в частині у зв'язку з високою забрудненістю» $[4 ; 5$, c. 6]. Дещо пізніше такі формулювання ставали перепоною для отримання посвідчення ліквідатора аварії на ЧАЕС, встановлення інвалідності.

Усвідомлюємо, що згадані вище спогади стосуються різних спеціальностей ліквідаторів, різних посад та часу перебування у зоні ураження, однак факт відсутності належного захисного спорядження та вимірювання доз опромінення констатують чи не всі учасники 
тих подій. Можемо вкотре стверджувати про відсутність усвідомлення реальної загрози з боку радіаційного опромінення, належного захисного оснащення ліквідаторів, чіткого документообігу та звітності. Аналіз офіційних документів, які наявні у відкритому доступі, підтверджують, що механізм державної влади і виконавських структур того часу не забезпечував рішучої й ефективної діяльності складного суспільного й господарського організму, тим більше за екстремальних обставин [6].

Усвідомлення реальності трагедії не відбулося й протягом кількох місяців після аварії (вочевидь дався взнаки брак об'єктивної інформації у засобах масової інформації). Спогади ліквідаторів рясні нехтуваннями правилами елементарної безпеки: «Спецодяг не всі хотіли носити. Улітку солдати працювали, їх попереджали: 3 доріжок не сходити, в ліс не заходити, тварин не чіпати, фрукти 3 дерев не їсти. Та хто ті рекомендації виконував, не могли втриматись. Фрукти гарні на вигляд, чому ж не з’їсти влітку в селі яблуко чи грушку. Котики, собачки лащаться - їх гладять, на руки беруть» [7]. Хтось із водіїв після дезактивації станції зупинився неподалік реактора й вирішив почитати книгу, а хтось, пробивши колесо автомобіля 3 написом «Хліб» не придумав нічого іншого, як дістати нове 3 автомобіля, який перебував на так званому «могильнику» (пункті тимчасової локалізації радіоактивних відходів, з відстійниками зараженої техніки включно).

Наведені вище приклади можуть розглядатися як з позицій звичайної халатності, слабосвідомості, так і з потреби власної свободи. Будь-яке здійснення пов'язане 3 вирішальним особистісним вибором, часто-густо через спонтанне творення рішень. Радіаційна небезпека невидима, а отже, цей внутрішній конфлікт чи банальна дилема вирішується через «Я» ліквідатора. У вільний від обов' язків час кожен обирає свою «загрозу», відповідно до своїх інтересів та планів. Рівень подібного безумства коливався від звичайної матеріальної вигоди до зреалізації ідеалів тодішнього тоталітарного режиму. Показовою щодо цього є ідея встановлення червоного прапора поряд з відкритим реактором. Ціна здоров'я, життя такої «прапороносності» становила 5 тис. крб» [8].

Але не все так однозначно. Маємо й інший спомин. «Цей подвиг був дуже потрібним. Прапор над трубою 4-го блоку, як прапор 
Перемоги, оповістив усіх нас та весь світ про те, що ми перемогли радіацію: припинили ії викид в атмосферу. Що світ знов може спати спокійно - аварія локалізована. І сьогодні, згадуючи ті роки, я повинен сказати, що прапор виконав свої функції й як звістка світу, й як мотиватор для тих, чий бій з радіацією тривав» [9]. Прикро констатувати, що усвідомлення безглуздості даного вчинку не усвідомлюється і з багатьма роками після трагедії. Нічого не значущі символи стають вищими за людське життя, «совкова» показуха до наших днів значною мірою визначає наші світоглядні орієнтири майбутнього. Лишається тільки погодитися 3 філософами-екзистенціоналістами, які ствердили думку, що абсурд не віддільний від людини та світу і виникає в їхній присутності.

Водночас, згадані свідчення постулюють так звану демістифікацію страху в середовищі ліквідаторів. Опинившись в епіцентрі катастрофи, освоївшись, кожен учасник тих подій для себе, рано чи пізно, долає страх, знервованість, які були пов'язані з надуманими переживаннями, які, до побаченого власними очима, були витвором уяви. Надумана «загроза» стає видимою, буденною, переживання значною мірою змінюються в бік позитиву. Додамо до цього й значний матеріальний стимул, який здиференціював цінності: сьогодні в тебе слава, гроші, відпустка, а колись - хвороби, каліцтво, байдужість. Реальність навколишньої дійсності звільняє тебе від побутованих у народі містичних уявлень про Чорнобиль, водночас створює непотрібний, недолугий, небезпечний для здоров'я героїзм.

Дефіцит інформації, невизначеність, кризові ситуації, в яких перебували ліквідатори, породив такий феномен, як соціальна міфотворчість. Міфотворення відбувається на рівні колективної психіки й зачіпає не так свідомість індивіда, як його емоції. У середовищі, в якому більше «байдикуєш», ніж працюєш (час перебування у зоні відчуження був регламентований), народився найбільш поширений міф про корисність червоного вина, алкоголю загалом у боротьбі 3 радіацією. «У Поліському офіційно панував «сухий закон», але в кожній групі, користуючись «інформацією» про те, що в японській Хіросімі від радіації менше постраждали алкоголіки, усі потроху вживали спиртне. Тоді навіть у середовищі лікарів побутувала насправді хибна думка, що алкоголь активно виводить радіоакти- 
вні елементи з організму» [10]. Цікаво, що теза про корисність алкоголю в малій кількості до нині не викорінилась із суспільної думки.

У живучості такого міфу не вбачаємо нічого особливого. Поперше, армійські алкогольні традиції міцно вкорінилися у свідомості народу ще в період Другої світової війни; по-друге, це достатньо дієвий чинник для тимчасової нейтралізації, або глушіння страху; потретє, своєрідна розвага, спосіб розвіяти нудьгу та сіру обиденність. Під дією алкоголю людина може безмотивовано радіти, почувати себе відновлено. Можемо впевнено стверджувати про втрату відчуття реального часу. Питання здоров'я також не актуальне, адже тут ти тільки ресурс, який експлуатують.

В умовах приреченості, тривоги, абсурдності та невідворотності, в яких опинилися ліквідатори аварії на ЧАЕС, важливе значення відігравав гумор, іронія. Саме вони давали можливість розрядити приховану «в душі» тривогу, певним чином компенсувати відсутність об'єктивної інформації, відволіктися від одноманітності тощо. Ця складова буття ліквідаторів не надто вітається дослідниками через нульову героїзацію чорнобильської катастрофи, водночас змушує учасників тих подій пригадати моменти, «які не можна розказати дітям». До речі чорнобильські афоризми значною мірою російськомовні, що вказує на зросійщеність командного військового складу СРСР. «Розважали солдатів не тільки... сумнівним гумором, а й американської комедією «Няня». Робилося це для того, аби ліквідатори йшли в боротьбу з невидимим злом без страху» [11]. I хоча названі ідіоми достатньо дискусійні, сам факт наявності специфічного чорнобильського гумору не викликає сумнівів. На чорнобильській станції медики над солдатами жартували: «А що, всі ще живі?»питали їх, зустрічаючи ввечері після зміни [12].

Комічне i, водночас, трагічне в Чорнобилі співіснувало поряд. По-різному можна сприймати прояви людяності щодо тварин, які перебували в зоні ураження, хоча, згідно з наказом, їх мали знищити. «Під час інспекції кошеня побачив генерал і наказав знищити тваринку. Йому відповіли: «Так!», але кошеня сховали, думаючи, що начальство більше не повернеться. А він приїхав вкотре $\mathrm{i}$, як на зло, кошеня знов потрапило на очі. Генерал розсердився, наказав вбити й показати труп. Усі почали думати, як врятувати кота Радика. Зрештою, взяли шматок м'яса, стару кролячу шапку й здрібнили все 
разом сікачем у відрі. Це місиво з шерстю принесли генералу. «Я попросив просто вбити, а ви, садисти, що витворили?!» - кричав той» [13]. Чи не приклад апогею абсурдної свідомості? Ліквідатори проживають відчуття незахищеності, самотності, душевного дискомфорту у зв'язку з несправедливістю та ефемерністю життя і разом 3 тим готовність чинити опір через сумнів і боротьбу, через покладання сенсу життя насамперед в автентичності існування людини.

Подвиг ліквідаторів-чорнобильців для багатьох «приречених» пов'язаний з усвідомленням його беззмістовності. Чи не апогеєм сарказму державного рівня можна вважати отримання грамоти ліквідаторами на ім'я неіснуючої дружини. Цей, здавалося б, незначний факт в один момент нівелює всю твою діяльність у зоні ураження. Ніхто не цікавиться тобою як особистістю, грамоти та подяки перетворюються на звичайний кольоровий клаптик паперу, сувенір на згадку. За такого стану речей нагороди Батьківщини сприймаються як такі, які не варті серйозного ставлення [2, с. 98]. Мужність, самопожертва, громадянська позиція стали предметом бутафорної вдячності, ганебним відкупом тодішнього бюрократичного свавілля.

Чорнобильська катастрофа репрезентувала новий трагічний досвід відчуттів, настроїв, переживань, здатних ставати сутнісними рисами, способами «бути», глибинно впливати на доленосні вчинки. Перебування у середовищі шкідливої та руйнівної для здоров'я радіації - це особливий тип амбівалентного переживання ліквідаторського буття. Ці переживання актуалізуються, проявляються на соціальному, біологічному і екзистенційному рівнях. Для їх подолання особистість використовує будь-які способи, що дають можливість вдало пристосуватися до умов, або загартувати себе від травматичних наслідків 3 метою обмеження руйнації і знецінення власного існування.

Тривожність і страх, як природні начала, спонукали в ліквідаторів бажання захиститися від радіаційної небезпеки, яка загрожує їхньому існуванню, віднайти механізми проходження крізь «радіаційне пекло». Через відсутність дієвих засобів радіаційного захисту людська свідомість змоделювала оборонні редути у вигляді «свинцевих жилетів», «суперчоботів», «омолоджувальної води» у вигляді алкоголю, «чорного» гумору та ін. Досвід Чорнобиля у свідченнях 
ліквідаторів продемонстрував низьку цінність життя в СРСР, торжество абсурдної жертовності та популізму. Водночас, трагізм ситуації ствердив й інші даності - прагнення до сенсу буття, свободи, самопожертви заради інших. I хочаназвані данності в умовах радіаційного середовища переплетені з абсурдністю, все ж таки констатують сильний потенціал суто людських властивостей - чуйності, доброти, дружелюбності, поваги. Ініціація радіацією не пройшла даремно як для самих ліквідаторів, так і для всього українського народу. Хочеться сподіватися, що незалежна українська держава все ж таки навчиться робити належні висновки зі свого трагічного минулого.

Чорнобильський досвід, наслідки аварії спонукають до загострення дискурсу на ще не промислених та непроговорених проблемах нашого сьогодення. Розгляд теми, безперечно, не вичерпується цим дослідженням і потребує подальшого осмислення, зокрема в аспекті практичної проблематики буття постраждалих в аварії на Чорнобильській атомній електростанції, до контексту глобальних проблем людства, перспектив розвитку науково-технічного прогресу і відповідальності за його наслідки, співвідношення трагедії особистості і суспільства в цілому.

\section{ЛІТЕРАТУРА}

1. Каганов Ю. О. «Радянська людина» в історіографічному дискурсі: радянська і дисидентська версії. Сумська старовина. 2018. № LIII. C. 22-30.

2. Пронин М. А. Экзистенция: забытый Чернобыль. Записки ликвидатора. М. : Канон+, 2016. 224 с.

3. Прокопчук С. Чорнобиль. Доля батальйону приречених. URL: https://www.ukrinform.ua/rubric-society/3234781-cornobil-dolabataljonu-prirecenih.html

4. Єленський В. «Наші хлопці вмирали у 30-35 років». Спогади про ліквідацію аварії на ЧАEC. URL: https://www.radiosvoboda. org/a/30577003.html

5. Литовченко В. П. У двобої з атомним монстром. Ніжинський вісник. 23 квітня 2016. С. 6.

6. Чорнобильська трагедія: Документи і матеріали / НАН України; Інститут історії України; Головне архівне управління при Кабіне- 
ті міністрів України; Центральний державний архів громадських об'єднань України. Київ : Наукова думка, 1996. 715 с.

7. Токарчук H. Чорнобиль: спогади очевидців. URL: https://ivisti.com/news/10320-chornobil-spogadi-ochevidcv.html

8. «Чим пахне?» - «Радіацією!»: спогади ліквідаторів аварії на ЧАEC з Придніпровської залізниці. URL: http://portal.uz.gov.ua/2021/ 04/30/chim-pakhne-radiacziyeyu-spogadi-likvidatoriv-avariyi-nachaes-z-pridniprovskoyi-zalizniczi

9. Чорнобиль: спогади ліквідаторів. Антоненко Сергій Валентинович. Кадри металургії. 2016. № 4(2707). С. 8.

10. Ільницький В. 3 Чорнобилем у серці. URL: https://www.uzhnu. edu.ua/uk/news/z-chornobilem-u-sertsi.htm

11. Гришина Д. Поїздка до Прип'яті разом із ліквідаторами ЧАЕС: спогади та сучасний вигляд міста. URL: https://vechirniy. kyiv.ua/news/52087

12. Босик Л. У 38 років потрапив у Чорнобиль. Сміття з реакторів прибирали вручну - розповідь ліквідатора. URL: https://volo dymyrets.city/ blogs/77559/u-38-rokiv-potrapiv-u-chornobil-smittyaz-reaktoriv-pribirali-vruchnu-rozpovid-likvidatora

13. Спогади чорнобильських «партизанів», або: «Врятувати рядового Радика». URL: https://armyinform.com.ua/2021/04/spogadychornobylskyh-partyzaniv-abo-vryatuvaty-ryadovogo-radyka

\section{REFERENCES}

Kahanov, Yu. O. (2018). "Soviet man" in historiographical discourse: Soviet and dissident versions. Sumska starovyna [Sumy antiquity], LIII, 22-30. [In Ukrainian].

Pronin, M. A. (2016). Existence: the forgotten Chernobyl. Notes of the liquidator. M.: Kanon+ [In Russian].

Prokopchuk, S. Chernobyl. The fate of the battalion of the doomed. Retrieved from https://www.ukrinform.ua/rubric-society/3234781-cornobil-dolabataljonu-prirecenih.html [In Ukrainian].

Ielenskyi, V. "Our boys died at the age of 30-35". Memories of the liquidation of the accident at Chaes. Retrieved from https://www.radiosvoboda. org/a/30577003.html [In Ukrainian].

Lytovchenko, V. P. (2016). In a duel with an atomic monster. Nizhynskyi visnyk [Nizhyn Herald], 23.04, 6. [In Ukrainian]. 
The Chernobyl tragedy: Documents and materials. (1996). Kyiv: Naukova dumka. [In Ukrainian].

Tokarchuk, N. Chernobyl: eyewitness accounts. Retrieved from https://ivisti.com/news/10320-chornobil-spogadi-ochevidcv.html [In Ukrainian].

"What does it smell like?" - "Radiation!": Memories of the liquidators of the Chernobyl accident from the Dnieper Railway. Retrieved from http://portal.uz.gov.ua/2021/04/30/chim-pakhne-radiacziyeyu-spogadilikvidatoriv-avariyi-na-chaes-z-pridniprovskoyi-zalizniczi [In Ukrainian].

Chernobyl: memories of liquidators. Antonenko Sergey Valentinovich. (2016). Kadry metalurhii [Personnel of metallurgy], 4 (2707), 8. [In Ukrainian].

Ilnytskyi, V. Z. Chernobyl in the heart. Retrieved from https://www.uzhnu. edu.ua/uk/ news/z-chornobilem-u-sertsi.htm [In Ukrainian].

Hryshyna, D. A trip to Pripyat with the liquidators Time: memories and modern view of the city. Retrieved from https://vechirniy.kyiv.ua/news/52087 [In Ukrainian].

Bosyk, L. At the age of 38 he went to Chernobyl. Garbage from the reactors was removed by hand - the liquidator's story. Retrieved from https://volodymyrets.city/blogs/77559/u-38-rokiv-potrapiv-u-chornobilsmittya-z-reaktoriv-pribirali-vruchnu-rozpovid-likvidatora [In Ukrainian].

Memoirs of Chernobyl "guerrillas", or: "Save Private Radik". Retrieved from https://armyinform.com.ua/2021/04/spogady-chornobylskyh-party zaniv-abo-vryatuvaty-ryadovogo-radyka [In Ukrainian].

\section{Viktor Lytovchenko}

Candidate of Philosophical Sciences (Ph.D.), Associate Professor of the Social and Humanities Sciences Department, Structure Subdivision of National University of Life and Environmental Sciences of Ukraine «Nizhyn Agrotechnical Institute»; Nizhyn, Ukraine; e-mail: viktorpl08@gmail.com; ORCID: https://orcid.org/0000-0003-0532-0188

\section{Existential dimensions of the Chernobyl disaster in the testimony of the first liquidators}




\begin{abstract}
The relevance of the chosen topic of the article is due to the lack of proper scientific discourse in the context of personal experiences of ordinary liquidators of the Chernobyl accident. The controversy of scientists in the Soviet Union focused on the causes and consequences of man-made disasters. At that time, the issues of constituting the value of human life, personal doubts and experiences, worldviews of liquidators in conditions of imminent and invisible danger were overlooked in scientific publications, or covered superficially. Evidence of human heroism and frivolity, open disregard for the basic rules of safety and the desire to secure themselves with simple folk methods, extreme manifestations of human selfishness and altruism are presented on the basis of open sources (fragmentary memories of the liquidators of the accident). The problem is extremely relevant because of the devastating consequences of an unprecedented catastrophe, Ukrainian society has once again failed to understand that human life is the greatest value on Earth. The analysis of memoriesconvictions of liquidators from the position of revealing existential markers of coexistence of human society in the conditions of radiation pollution is carried out. In the work, the existence of the hero-rescuer is determined by the concepts of "anxiety", "fear", "life", "humor" and others. It is concluded that the Chernobyl disaster revealed previously unknown manifestations of ambivalence in life personality, has become a test of our social maturity.
\end{abstract}

Keywords: chernobyl tragedy, radiation, radiation, liquidators, fear, anxiety. 